\title{
Tiller size/density compensation in grazed Tifton 85 bermudagrass swards ${ }^{(1)}$
}

\author{
André Fischer Sbrissia(2), Sila Carneiro da Silva( ${ }^{(3)}$, Cory Matthew ${ }^{(4)}$, \\ Carlos Augusto Brandão de Carvalho(2), Roberta Aparecida Carnevalli(i), \\ Luiz Felipe de Moura Pinto ${ }^{(5)}$, Jaílson Lara Fagundes ${ }^{(5)}$ and Carlos Guilherme Silveira Pedreira ${ }^{(3)}$
}

\begin{abstract}
The objective of this study was to evaluate the occurrence of the tiller size/density compensation mechanism in Tifton 85 bermudagrass swards grazed by sheep under continuous stocking. Treatments corresponded to four sward steady state conditions $(5,10,15$, and $20 \mathrm{~cm}$ of sward surface height), maintained by sheep grazing. The experimental design was a complete randomized block with four replicates. Pasture responses evaluated include: tiller population density, tiller mass, leaf mass and leaf area per tiller, and herbage mass. Tiller volume, leaf area index, tiller leaf/stem ratio, and tiller leaf area/volume ratio were calculated and simple regression analyses between tiller population density and tiller mass were performed. Measurements were made in December, 1998, and January, April, and July, 1999. The swards showed a tiller size/density compensation mechanism in which high tiller population densities were associated with small tillers and vice-versa, except in July, 1999. Regression analyses revealed that linear coefficients were steeper than the theoretical expectation of $-3 / 2$. Increments in herbage mass were attributable to increases in tiller mass in December and January. Leaf area/volume ratio values of Tifton 85 tillers were much lower than those commonly found for temperate grass species.
\end{abstract}

Index terms: Cynodon, leaf area index, mass, density, plant morphology.

\section{Compensação tamanho/densidade populacional de perfilhos em pastos de Tifton 85}

Resumo - O objetivo deste trabalho foi avaliar a ocorrência do mecanismo de compensação tamanho/ densidade populacional de perfilhos em pastagens de Tifton 85 (Cynodon spp.). Os tratamentos corresponderam a quatro condições de pasto $(5,10,15$ e $20 \mathrm{~cm}$ de altura), mantidas constantes por ovinos em regime de lotação contínua e taxa de lotação variável. O delineamento experimental foi o de blocos completos casualizados com quatro repetições. As variáveis densidade populacional de perfilhos, massa por perfilho, massa de folha por perfilho, área foliar por perfilho, massa de forragem, volume por perfilho, índice de área foliar, relação folha/haste e razão entre área foliar/volume do perfilho (R) foram avaliadas. Além disso, regressões simples foram realizadas entre densidade populacional de perfilhos e massa por perfilho. As medições foram realizadas em dezembro de 1998 e janeiro, abril e julho de 1999. Os resultados mostraram que pastagens de Cynodon spp. apresentaram um mecanismo de compensação tamanho/densidade populacional de perfilhos, em que maiores densidades populacionais estiveram associadas a perfilhos pequenos e vice-versa, exceto em julho de 1999. Análises de regressão mostraram coeficientes lineares menores que a expectativa teórica de $-3 / 2$. Aumentos em massa de forragem em dezembro e janeiro resultaram de aumentos em massa por perfilho. Os valores de $\mathrm{R}$ foram menores que aqueles encontrados para plantas de clima temperado, indicando um maior nível de integração clonal entre plantas de Tifton 85 .

Termos para indexação: Cynodon, índice de superfície foliar, massa, densidade, morfologia vegetal.

\footnotetext{
(1) Accepted for publication on September 4, 2003.

Extracted from M.Sc. dissertation presented by the first author to Escola Superior de Agricultura Luiz de Queiroz (Esalq), Piracicaba, SP. Sponsored by Fapesp.

(2) Esalq, Dep. de Zootecnia, Caixa Postal 09, CEP 13418-900 Piracicaba, SP. Fapesp fellow.

E-mail: sbrissia@bol.com.br, cabcarva@bol.com.br
}

${ }^{(3)}$ Esalq, Dep. de Zootecnia. E-mail: scdsilva@esalq.usp.br, cgspedre@esalq.usp.br

${ }^{(4)}$ Massey University, Institute of Natural Resources, Private Bag 11222, Palmerston North, New Zealand. E-mail: C.Matthew@massey.ac.nz

${ }^{(5)}$ Esalq, Dep. de Zootecnia. Capes fellow.

E-mail: racarnev@esalq.usp.br, omazzo@bol.com.br, ratinhojlf@yahoo.com.br 


\section{Introduction}

Defoliated grass swards exhibit tiller size/density compensation (SDC) with change in defoliation height (Bircham \& Hodgson, 1983; Davies, 1988; Matthew et al., 1995; Hernández Garay et al., 1999). As a consequence, short swards are characterized by a large population of small tillers and tall swards by a smaller population of large tillers (Bircham \& Hodgson, 1983; Grant at al., 1983). This pattern of self-regulation can be viewed as means by which pastures regulate leaf area index (LAI) in response to change in defoliation height, since tiller population density (TPD) is the component of the sward LAI in which changes in sward structure can be readily expressed (Matthew et al., 2000).

In grazed swards, however, there are limits to phenotypic plasticity represented by the maximum tiller size and the maximum tiller population density sustainable for a given species in a particular environment (Chapman \& Lemaire, 1993). Additionally, under very severe grazing, some grasses may lack organic reserves for bud release to increase tiller population density and pastures may collapse (Matthew et al., 1995).

This tiller size/density compensation issue has been discussed in terms of the $-3 / 2$ self-thinning rule originally described by Yoda et al. (1963), according to whom tiller mass and tiller population density would be inversely correlated, following a linear regression line with a $-3 / 2$ slope when considered in a logarithm scale. This line has also been called the species boundary line, and would represent the ceiling sward LAI for a given environment and upon which sward LAI would be constant (Chapman \& Lemaire, 1993; Matthew et al., 1995; Hernández Garay et al., 1999). However some authors (Matthew et al., 1995; Hernández Garay, 1999) have observed a systematic lack of fit between the field data and the theoretical expectation of $-3 / 2$, with the observed slope being steeper than $-3 / 2$. Sackville Hamilton et al. (1995) showed that a self-thinning slope of $-3 / 2$ is a theoretical expectation where LAI and a measure of plant leaf area/plant size ratio, $\mathrm{R}$, remain constant. Since swards grazed at different heights vary systematically in LAI (Bircham \& Hodgson, 1983; Matthew et al., 1995; Fagundes et al., 1999), it ensues that SDC in defoliated swards should follow slopes different from $-3 / 2$. This relationship has been studied recently for some temperate species, but for tropical grasses there are few data available.

The objective of this study was to evaluate the occurrence of the tiller size/density compensation in Tifton 85 bermudagrass swards grazed by sheep under continuous stocking.

\section{Material and Methods}

The experiment was carried out at Unidade Experimental de Plantas Forrageiras (UEPF), Departamento de Zootecnia, Escola Superior de Agricultura Luiz de Queiroz, Universidade de São Paulo, Piracicaba, SP, Brazil (22 ${ }^{\circ} 42^{\prime}$ S, $47^{\circ} 38^{\prime} \mathrm{W}, 546 \mathrm{~m}$ above sea level). Detailed measurements of sward status and SDC related variables were performed on four occasions during the experimental period: Dec. 15, 1998 - spring; Jan. 25, 1999 - summer; Apr. 7, 1999 autumn and July 4, 1999 - winter.

The experiment was set up on a Kandiufalfic Eutrudox (United Sates, 1990) with the following chemical characteristics: $\mathrm{pH}\left(\mathrm{CaCl}_{2}\right), 5.4$; organic matter, $37 \mathrm{~g} \mathrm{dm}^{-3} ; \mathrm{P}$, $99 \mathrm{mg} \mathrm{dm}^{-3} ; \mathrm{K}, 4.6 \mathrm{mmol}_{\mathrm{c}} \mathrm{dm}^{-3} ; \mathrm{Ca}, 75 \mathrm{mmol}_{\mathrm{c}} \mathrm{dm}^{-3} ; \mathrm{Mg}$, $26 \mathrm{mmol}_{\mathrm{c}} \mathrm{dm}^{-3} ; \mathrm{H}+\mathrm{Al}, 30 \mathrm{mmol}_{\mathrm{c}} \mathrm{dm}^{-3}$; sum of bases, $106 \mathrm{mmol}_{\mathrm{c}} \mathrm{dm}^{-3}$; cation exchange capacity, $136 \mathrm{mmol}_{\mathrm{c}} \mathrm{dm}^{-3}$; and base saturation, $78 \%$. No P fertilizer or lime was applied either at establishment or throughout the experimental period.

Pastures were established vegetatively in March 1996. In 1997, $150 \mathrm{~kg} \mathrm{ha}^{-1}$ of $\mathrm{N}$ was applied as ammonium sulphate. In 1998 pastures received $40 \mathrm{~kg} \mathrm{ha}^{-1}$ of $\mathrm{N}$ in January, July and September, $50 \mathrm{~kg} \mathrm{ha}^{-1}$ in October and $25 \mathrm{~kg} \mathrm{ha}^{-1}$ in December. For uniformity, all swards were cut to three $\mathrm{cm}$ height at the beginning of the experiment in March 1998. Sheep were then introduced to experimental units in May, when the target sward surface heights were reached. In 1999 nitrogen fertilizer was applied twice: $50 \mathrm{~kg} \mathrm{ha}^{-1}$ of $\mathrm{N}$ in February and $75 \mathrm{~kg} \mathrm{ha}^{-1}$ in March. Nitrogen application rates and timings were planned to generate enough herbage accumulation to maintain at least two animals per experimental unit throughout the experimental period (December 15, 1998 to July 4, 1999). Present and historical (80-years average) climatic conditions for the experimental site are presented in Table 1.

Treatments of sward surface height (SSH) were assigned to $400 \mathrm{~m}^{2}$ experimental units (plots) in a complete randomized block design with four replications. The Tifton 85 bermudagrass was allowed to grow to the $\mathrm{SSH}$ of $5,10,15$ or $20 \mathrm{~cm}$ before grazing sheep were added to 
maintain swards at the target SSH through continuous stocking with variable stocking rate. Sward height was monitored twice a week by 20 sward stick readings per plot (Frame, 1981). Animals were either added or removed from experimental units when swards were $20 \%$ above or below target $\mathrm{SSH}$, respectively.

For herbage mass evaluation $\left(\mathrm{kg} \mathrm{m}^{-2}\right)$, two $0.25 \mathrm{~m}^{2}$ quadrats were used per plot. Quadrats were placed on sites representing the target SSH and the herbage was cut to ground level using electric shears. Samples were conditioned in plastic bags and stored in a cold room. Each sample was washed to remove soil and dung contamination and dried in a forced draught oven at $65^{\circ} \mathrm{C}$ for 48 hours prior to weighing.

Measurements related to individual tiller traits were made in an $8.5 \times 14.7 \mathrm{~cm}$ quadrat. Quadrats were placed on sites representing the target $\mathrm{SSH}$ and two samples per plot were cut to ground level using scissors and razor blades. A high degree of homogeneity in SSH was achieved, particularly in short swards. Even so, there was some degree of variability in SSH across individual experimental units. To ensure measurements were related to the intended sward state conditions, sampling areas were selected by using a sward stick to place quadrats on sites representing the target SSH. The cut material was placed in plastic bags previously wetted and conditioned in a styrofoam box with ice to reduce plant dehydration and respiration. All samples were taken to the laboratory and stored in a cold room $\left(2^{\circ} \mathrm{C}\right)$

Twenty tillers were selected at random from the quadrat samples. These were weighed and the average fresh mass per tiller calculated. After weighing, all green leaf laminae were detached from the tiller axis and their total area measured using a LI-3100 leaf area meter. Values were used to calculate the average leaf area per tiller. Leaf laminae were then placed into small paper bags and dried in a forced draught oven at $65^{\circ} \mathrm{C}$ for 48 hours. The same procedure was used for the combined stem (stem + leaf sheath) and senescent leaf material. After drying, samples were weighed and the average live lamina dry mass and stem/senescent material per tiller calculated. Total dry mass per tiller was calculated accordingly.

Tiller population density (TPD) was obtained through the following calculation:

$\mathrm{TPD}=\mathrm{HM}\left(\mathrm{kg} \mathrm{m}^{-2}\right) / \mathrm{TM}\left(\mathrm{kg} \mathrm{tiller}^{-1}\right)$

where HM is the herbage mass and TM is the individual tiller mass.

Sward Leaf Area Index (LAI) was determined according to the following calculation:

\section{$\mathrm{LAI}=\mathrm{TPD} \times \mathrm{LAT}$}

where TPD is the tiller population density (tillers $\mathrm{m}^{-2}$ ) and LAT is the leaf area per tiller $\left(\mathrm{m}^{2}\right.$ tiller $\left.{ }^{-1}\right)$.

Table 1. Average monthly air temperatures (maximum, minimum and mean), rainfall and sunshine hours from November, 1998 to July, 1999 and the 80-year averages.

\begin{tabular}{|c|c|c|c|c|c|}
\hline Month/year & Maximum & Minimum $\left({ }^{\circ} \mathrm{C}\right)$ & Mean & Rainfall (mm) & Sunshine (h/day) \\
\hline \multicolumn{6}{|l|}{ November } \\
\hline 1998 & 30.0 & 16.4 & 23.2 & 26.6 & 7.8 \\
\hline 80 -vear mean & 29.6 & 16.7 & 23.1 & 130.0 & 7.4 \\
\hline \multicolumn{6}{|l|}{ December } \\
\hline 1998 & 30.0 & 19.2 & 24.6 & 292.6 & 6.1 \\
\hline 80 -year mean & 29.6 & 18.1 & 23.9 & 200.2 & 6.6 \\
\hline \multicolumn{6}{|l|}{ January } \\
\hline 1999 & 31.4 & 19.0 & 25.2 & 210.8 & 7.7 \\
\hline 80 -year mean & 30.0 & 18.2 & 24.0 & 142.4 & 6.8 \\
\hline \multicolumn{6}{|l|}{ February } \\
\hline 1999 & 30.7 & 20.0 & 25.4 & 198.3 & 5.4 \\
\hline 80 -year mean & 30.2 & 19.0 & 24.6 & 185.9 & 6.5 \\
\hline \multicolumn{6}{|l|}{ March } \\
\hline 1999 & 31.4 & 19.0 & 25.2 & 210.8 & 7.7 \\
\hline 80 -year mean & 30.0 & 18.2 & 24.0 & 142.4 & 6.8 \\
\hline \multicolumn{6}{|l|}{ April } \\
\hline 1999 & 28.5 & 15.2 & 21.9 & 89.0 & 8.1 \\
\hline 80 -vear mean & 28.3 & 15.4 & 21.8 & 64.8 & 7.5 \\
\hline \multicolumn{6}{|l|}{ May } \\
\hline 1999 & 25.4 & 11.2 & 18.3 & 51.3 & 7.4 \\
\hline 80 -year mean & 26.1 & 12.1 & 19.1 & 52.7 & 7.2 \\
\hline \multicolumn{6}{|l|}{ June } \\
\hline 1999 & 23.9 & 11.0 & 17.4 & 68.6 & 6.0 \\
\hline 80 -year mean & 24.9 & 10.3 & 17.6 & 44.5 & 7.1 \\
\hline \multicolumn{6}{|l|}{ July } \\
\hline 1999 & 26.8 & 12.0 & 19.2 & 2.7 & 6.7 \\
\hline 80 -vear mean & 25.3 & 9.5 & 17.4 & 26.8 & 7.8 \\
\hline
\end{tabular}


Average tiller volume was estimated by a technique based on the immersion of tillers in liquids with known apparent densities. Water $\left(1,000 \mathrm{~kg} \mathrm{~m}^{-3}\right.$ at room temperature) and a lubricant oil $\left(902 \mathrm{~kg} \mathrm{~m}^{-3}\right.$ at $\left.20^{\circ} \mathrm{C}\right)$ were used as references. Tillers floated in water but sank in oil, so it was assumed that tiller apparent density was around $950 \mathrm{~kg} \mathrm{~m}^{-3}$. This degree of precision in measuring tiller apparent density was considered sufficiently robust, because it represented a maximum 5\% error in the final tiller volume estimates. Average volume per tiller was calculated as follow:

$\mathrm{TV}\left(\mathrm{m}^{3}\right)=\mathrm{TFM} / \mathrm{TAD}$

where TFM is the tiller fresh mass $(\mathrm{kg})$ and TAD is the tiller apparent density.

The tiller leaf area/volume ratio $(\mathrm{R})$ proposed by Sackville Hamilton et al. (1995) was calculated as follow: $\mathrm{R}=\mathrm{LAT}^{3 / 2} / \mathrm{TV}$

where LAT is the leaf area per tiller $\left(\mathrm{m}^{2}\right)$ and TV is the tiller volume $\left(\mathrm{m}^{3}\right)$. LAT has the exponent $3 / 2$ to make the area/volume ratio dimensionless, so giving a measure of tiller shape (Sackville Hamilton et al., 1995).

Linear regressions based on Ordinary Least Square between tiller mass (TM) and tiller population density (TPD) were generated using treatment means, which corresponded to four sets of paired data for each evaluation period. Following procedure described by Sackville Hamilton et al. (1995), slopes generated by Ordinary Least Square analysis were divided by the correlation between $\log (\mathrm{TM})$ and $\log (\mathrm{TPD})$, resulting in the Reduced Major Axis (RMA) slopes, which were used for treatment comparisons.

Estimates of the correction factors for the deviations between the actual regression lines and the $-3 / 2$ line for each of the four evaluations were made according to Matthew et al. (1995):

$\mathrm{C}_{\mathrm{a}}=\Delta \log \left(\mathrm{LAI}^{3 / 2}\right) / \Delta \log (\mathrm{TPD})$

and

$\mathrm{C}_{\mathrm{r}}=\Delta \log (\mathrm{R}) / \Delta \log (\mathrm{TPD})$

where LAI is the sward leaf area index; TPD is the tiller population density (number $\mathrm{m}^{-2}$ ) and $\mathrm{R}$ is the tiller leaf area/volume ratio.

$\mathrm{C}_{\mathrm{a}}$ and $\mathrm{C}_{\mathrm{r}}$ were calculated as being the slopes for the regressions between sward LAI and TPD, and R and TPD, respectively. According to Matthew et al. (1995), the perpendicular distance between any given point and the $-3 / 2$ line placed below the plotted points can be used as a sward productivity index. In this experiment the perpendicular distance between the plotted points for $\log (\mathrm{TM}) \mathrm{x}$ $\log (\mathrm{TPD})$ and the $-3 / 2$ line (constant LAI and R) was calculated.
Data were analysed using PROC GLM (General Linear Models) and PROC REG from the statistical package SAS (Statistical Analysis System). Analysis of variance was performed using the Repeated Measures option since all variables were measured sequentially (December, January, April and July) throughout the experimental period, and comparisons between treatment means were performed using LSMEANS.

\section{Results and Discussion}

Although ANOVA results revealed no significant time of the year effect, there was an increase in tiller population density (TPD) from December to January (Table 2). The lower population density observed in December was probably a consequence of a dry spell in November (Table 1). In December, when rainfall returned, population increased. Korte (1986) and Davies (1988) related the increase in tiller population in summer to increased light and increased canopy LAI (Fagundes et al., 1999). The data from December, January and April show a pattern for TPD decreasing with the increase of sward surface height (Table 2). In July there was a rosette formation that changed this trend of TPD pattern. These results are consistent with data generated from temperate forages, where higher TPD were associated with more severely defoliated swards, but where TPD can fall under extremely severe defoliation (Bircham \& Hodgson, 1983; Matthew et al., 1995; Hernández Garay et al., 1999).

In July, a reverse trend of increasing TPD with increasing sward surface height over the $10 \mathrm{~cm}$ to $20 \mathrm{~cm}$ height range was observed. This is explained by the formation, at greater cutting heights, of crowns containing numerous small tillers originating from the nodes of decapitated reproductive stems (Carnevalli \& Silva, 1999).

Mortality in a self-thinning stand occurs because competition for light (Lonsdale \& Watkinson, 1982; Sackville Hamilton et al., 1995). Fagundes et al. (1999) observed that in the $5 \mathrm{~cm}$ swards around $62 \%$ of the incident light reached the soil surface in September, 1998, and increased to $95 \%$ in December, 1998. By contrast, in pastures kept at $20 \mathrm{~cm}$, the corresponding values were around $18 \%$ in August, 1998 and, in some situations, approximately $3 \%$. The low amount of incident light reaching the soil surface is a factor associated with reduced tillering in laxly defoliated swards (Langer, 1979); also is the 
reduced red/far red ratio of the available light within sward canopy (Casal et al., 1985). In addition, the leaves at the base of tillers growing in an environment with reduced light availability have a major reduction in photosynthetic activity, potentially leading to a negative C balance (Parsons et al., 1983) and accelerated senescence/death of leaves and tillers that support them (Sackville Hamilton et al., 1995).

According to Chapman \& Lemaire (1993), grass species are limited in the range over which they exhibit plasticity through increases in tiller population density with reductions in sward surface height (SSH), and these limits arise because of the inability of certain grasses to reduce sheath length to maintain leaf material below a particular cutting height. This plasticity limit was also discussed by Matthew et al. (1995), and was found to be around $2 \mathrm{~cm} \mathrm{SSH} \mathrm{for}$ Lolium perenne, but varying with season, in which high defoliation intensity can, under certain circumstances, restrict tillering activity in grass plants. In April, swards maintained at $5 \mathrm{~cm}$ had a lower TPD than the ones at $10 \mathrm{~cm}$, indicating that $5 \mathrm{~cm} \mathrm{SSH}$ was below the plastic limit for Tifton 85 . This could be related to the reproductive phase observed on most swards at that time of the year.

There was an increase in individual tiller mass, leaf mass, and volume as SSH increased from 5 to $20 \mathrm{~cm}$ (Table 2). These results corroborate those reported for temperate forage plants in which taller swards had higher values for tiller mass, leaf mass per tiller (Matthew et al., 1995; Hernández Garay et al., 1999) and tiller volume (Matthew et al., 1995) than shorter ones. The highest values for tiller mass, leaf mass per tiller and tiller volume were observed in December (Table 2), a likely consequence of the low rainfall in November (Table 1), since other growth factors such as light availability, mineral nutrients and temperature were not limiting, and plants probably continued to accumulate carbon via photosynthesis but did not generate growth to commensurate with that accumulation.

Herbage mass measured in December and July was higher than that in January and April (Table 3). Values of herbage mass can be viewed as a result of the sum of the mass of all individual tillers per square meter. Thus, a reduced tiller population density observed in taller swards in December and January was compensated by a proportionately higher tiller mass, which ultimately determined the higher values of herbage mass (Table 2). Volenec \& Nelson (1983) recognized that tiller mass can be more important than tiller population density in determining sward productivity, or vice-versa, depending on the circumstances. Tiller population density was more important than tiller mass as a determinant of herbage mass particularly for the $10 \mathrm{~cm} \mathrm{SSH}$ in April, where

Table 2. Tiller population density, tiller mass, leaf mass per tiller and tiller volume in Tifton 85 pastures continuously stocked by sheep.

\begin{tabular}{|c|c|c|c|c|c|c|}
\hline \multirow[t]{2}{*}{ Month } & \multicolumn{4}{|c|}{ Sward surface height $(\mathrm{cm})$} & \multirow[t]{2}{*}{ Significance level } & \multirow[t]{2}{*}{ Mean \pm SEM $^{(I)}$} \\
\hline & 5 & 10 & 15 & 20 & & \\
\hline \multicolumn{7}{|c|}{ Tiller population density (tillers $\mathrm{m}^{-2}$ ) } \\
\hline Dec. & 16,320 & 13,350 & 8,910 & 7,170 & $*$ & $11,440 \pm 1,360$ \\
\hline Jan. & 17,730 & 14,850 & 14,230 & 13,550 & & $15,090 \pm 2,380$ \\
\hline Apr. & 10,930 & 17,415 & 16,260 & 13,760 & $*$ & $14,590 \pm 2,520$ \\
\hline July & 18,820 & 9,300 & 13,360 & 21,330 & & $15,700 \pm 4,940$ \\
\hline \multicolumn{7}{|c|}{ Tiller mass (mg tiller ${ }^{-1}$ ) } \\
\hline Dec. & 22.8 & 40.8 & 84.9 & 123.9 & $* *$ & $68.1 \pm 13.23$ \\
\hline Jan. & 12.3 & 26.6 & 36.2 & 54.9 & $* *$ & $2.5 \pm 7.88$ \\
\hline Apr. & 20.1 & 26.2 & 34.8 & 59.5 & $*$ & $35.1 \pm 6.62$ \\
\hline July & 20.8 & 51.5 & 52.7 & 67.8 & ns & $48.2 \pm 19.36$ \\
\hline \multicolumn{7}{|c|}{ Leaf mass per tiller (mg tiller ${ }^{-1}$ ) } \\
\hline Dec. & 9.1 & 15.3 & 27.6 & 35.2 & $* * *$ & $21.8 \pm 1.61$ \\
\hline Jan. & 5.9 & 12.3 & 15.1 & 21.0 & $* *$ & $3.6 \pm 2.21$ \\
\hline Apr. & 8.4 & 9.6 & 13.7 & 20.5 & $* *$ & $13.1 \pm 1.74$ \\
\hline July & 9.8 & 21.3 & 24.5 & 21.7 & $*$ & $19.3 \pm 4.62$ \\
\hline \multicolumn{7}{|c|}{ Tiller volume $\left(\mathrm{cm}^{3}\right.$ tiller $\left.{ }^{-1}\right)$} \\
\hline Dec. & 0.133 & 0.238 & 0.497 & 0.725 & $* * *$ & $0.398 \pm 0.077$ \\
\hline Jan. & 0.072 & 0.155 & 0.211 & 0.321 & $*$ & $0.189 \pm 0.046$ \\
\hline Apr. & 0.124 & 0.191 & 0.319 & 0.815 & $*$ & $0.362 \pm 0.239$ \\
\hline July & 0.121 & 0.301 & 0.308 & 0.396 & ns & $0.281 \pm 0.113$ \\
\hline
\end{tabular}


swards were below their plastic limit when kept at $5 \mathrm{~cm} \mathrm{SSH}$.

The highest values of leaf area per tiller were observed in December but there was no statistically significant time of the year effect on sward leaf area index (LAI) (Table 3). Among all the structural characteristics that determine LAI, TPD allows for a greater flexibility of plants for adjusting to different defoliation regimes, and this is why LAI is optimized in intensively grazed swards through a high population of small tillers. Conversely, in laxly-grazed swards, optimization of LAI is achieved through a low population of bigger tillers (Matthew et al., 2000). Despite the highest values of leaf area per tiller reached in December, LAI did not follow the same pattern because TPD tended to increase during the season as leaf area per tiller decreased, resulting in a fairly constant sward LAI throughout the experiment.

With the exception of July, when the normal pattern of size/density compensation with increasing sward height was reversed by the formation of rosettes, leaf area per tiller increased with increase in $\mathrm{SSH}$, and was the principal contributor to a strong positive correlation between LAI and SSH (Table 3 ).

Tiller leaf/stem ratio was generally higher at low $\mathrm{SSH}$ than at high SSH, and was significant $(\mathrm{P}<0.01)$ in December and January. Conversely, the measure of tiller geometry, R, tended to be highest at higher $\mathrm{SSH}$, although this trend was not statistically significant. The reason for the contrasting values of the two measures of tiller geometry was explained by Hernández Garay et al. (1999) in their work with miniature swards of perennial ryegrass. They also found an increase in $\mathrm{R}$ and decrease in tiller leaf/ pseudostem ratio at high SSH. Leaf/pseudostem ratio approximately reflects simple area/volume ratio, which decreases as size increases for any given geometrical shape. The conversion to a dimensionless ratio, $R$, by raising leaf area to the $3 / 2$ power removes the size effect, and reveals that larger tillers in fact tend to have proportionally longer leaves and shorter stems than smaller tillers simply scaled up in size. Additionally, increments in SSH can lead to decreased tiller leaf/stem ratios simply because in order to support the mass of leaves, stem diameter is altered proportionally to the strength required to support them, and not isometrically to the organ mass (McMahon, 1973; McMahon \& Kronauer, 1976; Niklas, 1994). However, if this was the dominant mechanism controlling tiller geometry, then $\mathrm{R}$ would decrease rather than increase with increasing tiller size, indicating that this effect can be assumed to be minor.

The overall mean value for $\mathrm{R}$ was around 15 (Table 4). Hernández Garay et al. (1999) reported $R$ values around 50 for perennial ryegrass and those values became higher as SSH increased, indicating that perennial ryegrass grew by developing proportionally more leaf length than stem length per tiller, as discussed above. In order to visualize what this difference in $\mathrm{R}$ means, the $\mathrm{R}$ value for a sphere (9.45) can be considered. In calculating $R$, the surface area of pseudostem is not taken into account and only one side of the leaf is considered, but a tiller of

Table 3. Herbage mass, leaf area per tiller and sward leaf area index in Tifton 85 pastures continuously stocked by sheep.

\begin{tabular}{|c|c|c|c|c|c|c|}
\hline \multirow[t]{2}{*}{ Month } & \multicolumn{4}{|c|}{ Sward surface height $(\mathrm{cm})$} & \multirow[t]{2}{*}{ Significance level } & \multirow{2}{*}{ Mean \pm SEM $^{\text {II }}$} \\
\hline & 5 & 10 & 15 & 20 & & \\
\hline \multicolumn{7}{|c|}{ Herbage mass $\left(\mathrm{kg} \mathrm{dm} \mathrm{m}^{-2}\right)$} \\
\hline Dec. & 0.37 & 0.51 & 0.68 & 0.84 & $* * *$ & $0.60 \pm 0.05$ \\
\hline Jan. & 0.20 & 0.37 & 0.48 & 0.66 & *** & $0.43 \pm 0.03$ \\
\hline Apr. & 0.21 & 0.42 & 0.53 & 0.75 & *** & $0.48 \pm 0.02$ \\
\hline July. & 0.37 & 0.46 & 0.62 & 0.79 & $* *$ & $0.56 \pm 0.05$ \\
\hline \multicolumn{7}{|c|}{ Leaf area per tiller $\left(\mathrm{cm}^{2}\right.$ tiller $\left.{ }^{-1}\right)$} \\
\hline Dec. & 1.19 & 1.96 & 3.82 & 5.01 & **** & $2.81 \pm 0.47$ \\
\hline Jan. & 1.08 & 1.76 & 2.02 & 3.38 & ** & $2.06 \pm 0.37$ \\
\hline Apr. & 1.36 & 1.47 & 2.31 & 3.24 & $* *$ & $2.10 \pm 0.28$ \\
\hline Julv. & 1.39 & 3.17 & 3.46 & 2.64 & * & $2.66 \pm 0.53$ \\
\hline \multicolumn{7}{|c|}{ Leaf area index } \\
\hline Dec. & 1.94 & 2.54 & 3.52 & 3.63 & ns & $2.90 \pm 0.77$ \\
\hline Jan. & 1.90 & 2.48 & 2.74 & 4.16 & $* * *$ & $2.82 \pm 0.28$ \\
\hline Apr. & 1.46 & 2.47 & 3.46 & 4.26 & $* * *$ & $2.91 \pm 0.37$ \\
\hline July & 2.50 & 2.89 & 4.48 & 3.83 & * & $3.42 \pm 0.60$ \\
\hline
\end{tabular}

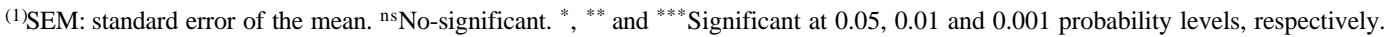


Cynodon spp. has only about 2 to 5 times the leaf area as the surface of a sphere of the same volume, whereas a tiller of Lolium has several times that leaf area. A low $\mathrm{R}$ value implies a high carbon cost for producing new leaf area, and such a plant might be expected to be uncompetitive. However, a plant with lower $\mathrm{R}$ value could maintain competitiveness having a higher level of clonal integration, since the $R$ value of an object which is a cluster of similar modules is much greater than the $\mathrm{R}$ value of a module in isolation (Matthew et al., 1995). Those authors showed that the $R$ value in alfalfa (which has a high degree of integration among shoots since they are all generated from common crowns) is higher when calculations are based on the whole plant rather than on single shoots by a factor of $n^{1 / 2}$, where $n$ is the number of shoots per crown. Table 4 also presents $R$ values assuming an hypothetical clonal integration among four tillers for Tifton 85. Under this assumption, $R$ values increased two-fold in all situations and became closer to values reported by Hernández Garay et al. (1999) for perennial ryegrass. Thus, the contrasting $\mathrm{R}$ values for Cynodon spp. measured in this experiment and for Lolium measured by Matthew et al. (1995) and Hernández Garay et al. (1999) lead to the hypothesis that a higher $\mathrm{R}$ value or a higher degree of clonal integration are alternative strategies available to a plant to increase competitiveness.

An additional advantage of clonal integration that has been pointed by Chapman et al. (1992) is that species that display strong physiological integration, a highly tillered or highly branched plant structure, should have an advantage because there are more intermodule linkages and, therefore, more intermodule resource fluxes would operate to buffer whole-plant growth against localized environmental variation (e.g., partial defoliation) affecting only part of a clone. This is in agreement with field observations of this experiment where a new cluster of tillers was formed along a stolon at regular intervals of three phytomers (node with roots and a daughter tiller followed by two successive leaves). Description of this pattern of growth and development of Cynodon grasses has not been found previously in the literature. Another consequence of this strategy is that Tifton 85 pastures may acquire competitive advantage through clonal integration of tillers. The pattern of growth observed in field conditions would suggest that a first leaf would support root development, a second, the tiller development and a third, the stolon internode elongation (Sbrissia et al., 2001), revealing another potential fundamental difference in growth strategy between Tifton 85 and perennial ryegrass. Further studies under controlled conditions are necessary, however, to elucidate the degree and nature of this integration in order to allow a better understanding of plant persistence, competitive ability and productivity.

Simple regression analyses between tiller mass and population density from December, January and April revealed significant functional linear relationships (Table 5). The fitted slopes $\left(\beta_{1}\right)$ were steeper than the theoretical expectation of $-3 / 2$. According to Sackville Hamilton et al. (1995), a -3/2

Table 4. Tiller leaf/stem ratio, tiller leaf area/volume ratio (R), and tiller leaf area/volume ratio assuming a clonal integration of four tillers (R1) in Tifton 85 pastures continuously stocked by sheep.

\begin{tabular}{|c|c|c|c|c|c|c|}
\hline \multirow[t]{2}{*}{ Month } & \multicolumn{4}{|c|}{ Sward surface height $(\mathrm{cm})$} & \multirow[t]{2}{*}{ Significance level } & \multirow[t]{2}{*}{ Mean \pm SEM $^{(\text {(I) }}$} \\
\hline & 5 & 10 & 15 & 20 & & \\
\hline \multicolumn{7}{|c|}{ Tiller leaf/stem ratio: } \\
\hline Dec. & 0.73 & 0.81 & 0.55 & 0.46 & $* *$ & $0.64 \pm 0.13$ \\
\hline Jan. & 0.97 & 1.07 & 0.76 & 0.68 & $* *$ & $0.87 \pm 0.13$ \\
\hline Apr. & 0.85 & 0.69 & 0.68 & 0.63 & ns & $0.71 \pm 0.11$ \\
\hline July & 0.91 & 0.81 & 1.27 & 0.83 & & $0.96 \pm 032$ \\
\hline \multicolumn{7}{|c|}{ Single tiller leaf area/volume ratio $(\mathrm{R})$} \\
\hline Dec. & 9.94 & 12.50 & 16.58 & 18.19 & ns & $14.30 \pm 4.60$ \\
\hline Jan. & 18.79 & 17.24 & 13.88 & 19.74 & ns & $17.41 \pm 4.09$ \\
\hline Apr. & 13.14 & 9.95 & 14.66 & 14.68 & nis & $13.11 \pm 2.27$ \\
\hline Juy & 13.70 & 19.54 & 22.88 & 12.46 & $*$ & $17.15 \pm 3.05$ \\
\hline \multicolumn{7}{|c|}{ Cloned tiller leaf area/volume ratio (R1) } \\
\hline Dec. & 19.88 & 25.00 & 33.16 & 36.38 & ns & $28.60 \pm 9.20$ \\
\hline Jan. & 37.58 & 34.48 & 27.76 & 39.48 & ns & $34.82 \pm 8.18$ \\
\hline Apr. & 26.28 & 19.90 & 29.32 & 29.36 & ns & $26.22 \pm 4.54$ \\
\hline July & 27.40 & 39.04 & 45.76 & 24.92 & $*$ & $34.30 \pm 6.10$ \\
\hline
\end{tabular}

${ }^{(1)}$ SEM: standard error of the mean. ${ }^{\mathrm{ns}} \mathrm{No}-$ significant. ${ }^{*},{ }^{* *}$ and ${ }^{* * *}$ Significant at $0.05,0.01$ and 0.001 probability levels, respectively. 
line would be a theoretical expectation when LAI and $\mathrm{R}$ remained constant. Since LAI varied with $\mathrm{SSH}$ (Table 4), it was expected that the slopes would be different from -3/2. Hernández Garay et al. (1999) also found slopes steeper than $-3 / 2$ (close to $-5 / 2$ ) for perennial ryegrass swards.

The slope corrections for change in leaf area with increasing $\mathrm{SSH}\left(\mathrm{C}_{\mathrm{a}}\right)$ and change in tiller leaf area:volume ratio $(R)\left(C_{r}\right)$ proved to be effective in accounting for the deviations between the calculated slope lines and the $-3 / 2$ theoretical expectation in December and January. One of the main factors that could have influenced the discrepancy between the observed slope and the value predicted by $\mathrm{C}_{\mathrm{a}}$ and $\mathrm{C}_{\mathrm{r}}$ in April, could be the effect of canopy size on reproductive growth presented by Tifton 85 , where swards at different SSH flowered at different times. This could have modified sward structure and affected key variables used for predicting the slopes: tiller population density, leaf area per tiller and tiller volume (Tables 2 and 3). This seems to confirm, however, that the equations proposed by Matthew et al. (1995) are robust enough to account for and explain the deviation from the $-3 / 2$ SDC line for Tifton 85 swards within the range of SSH studied. In January and April the calculated slopes were much higher than those observed for ryegrass (Matthew et al., 1995; Hernández Garay et al., 1999), suggesting that a less drastic reduction in tiller population density followed the increases in SSH for the range of sward heights studied.
Additionally, the estimated values of $\mathrm{C}_{\mathrm{a}}$ were higher than those of $\mathrm{C}_{\mathrm{r}}$, indicating that, as in the perennial ryegrass (Matthew et al., 1995; Hernández Garay et al., 1999), the variation in sward LAI is the main factor causing the tiller size/density compensation in Tifton 85 pastures. The variation in $\mathrm{R}$ is a comparatively minor element of plant growth strategy in the vegetative phase, but $R$ falls in the reproductive phase, allowing the sward to accommodate greater tiller population density than would otherwise have been the case. This is similar to perennial ryegrass (Matthew et al., 1995), but not necessarily true for all grasses.

Matthew et al. (1995) suggested that the distance between any given point defined by its coordinates tiller mass and population density (both in a log scale) and an arbitrarily positioned theoretical $-3 / 2$ size/density compensation line can be viewed as a sward productivity index. As demonstrated by Sackville Hamilton et al. (1995), the $-3 / 2$ line defines a situation where LAI is constant. It follows that the greater the distance between the observed points and a $-3 / 2$ line placed below those points, the higher the sward LAI and, consequently, the bigger the sward capacity to accumulate herbage dry matter. This hypothesis was confirmed for temperate species in micro swards (Hernández Garay et al., 1999) and in field conditions (Bahmani et al., 1997; Hernández Garay et al., 1997).

Simple correlation coefficients between the perpendicular distance of the observed points from the $-3 / 2$ line and the actual sward LAI (Table 6) indicated

Table 5. Linear coefficients $\left(\beta_{0}\right)$, intercepts $\left(\beta_{1}\right)$, determination coefficients $\left(R^{2}\right)$ and levels of significance (LS) for the $\log _{10} \times \log _{10}$ regressions between TPD and TW and $C_{a}$ and $C_{r}$ values in Tifton 85 pastures continuously stocked by sheep ${ }^{(1)}$.

\begin{tabular}{lccccccc}
\hline Month & $\beta_{0}$ & $\beta_{1}$ & $\mathrm{R}^{2}$ & $\mathrm{LS}$ & $\mathrm{Ca}$ & $\mathrm{Cr}$ & Predicted slope $(\beta)^{(2)}$ \\
\hline Dec. & 3.85 & -2.02 & 0.989 & $* *$ & $1.19(0.06)$ & $-0.74(0.02)$ & -1.95 \\
Jan. & 17.60 & -5.37 & 0.973 & $* *$ & $4.16(0.12)$ & $-0.07(0.08)$ & -5.59 \\
Apr. & 10.00 & -3.45 & 0.996 & $*$ & $3.42(0.09)$ & $-1.86(0.09)$ & -3.06 \\
\hline (1)Numbers in parenthesis are standard errors of the estimate. ${ }^{(2)}$ Calculated according to Matthew et al. (1995) where slope $=-\left(\mathrm{C}_{\mathrm{a}}+\mathrm{C}_{\mathrm{r}}+3 / 2\right){ }^{*}$ and \\
*** ${ }^{*}$ Significant at 0.05 and 0.01 probability levels, respectively.
\end{tabular}

Table 6. Correlation coefficients ( $r$ ) between the distance of points with coordinates $x / y$ (in a log scale) and the $-3 / 2$ line and the sward leaf area index (LAI) in Tifton 85 pastures continuously stocked by sheep.

\begin{tabular}{|c|c|c|c|c|c|c|}
\hline \multirow[t]{2}{*}{ Sward surface height $(\mathrm{cm})$} & \multicolumn{2}{|c|}{ December } & \multicolumn{2}{|c|}{ January } & \multicolumn{2}{|c|}{ April } \\
\hline & Distance & LAI & Distance & LAI & Distance & LAI \\
\hline 5 & 0.207 & 1.94 & 0.146 & 1.90 & 0.145 & 1.46 \\
\hline 10 & 0.276 & 2.54 & 0.276 & 2.48 & 0.376 & 2.47 \\
\hline 15 & 0.307 & 3.52 & 0.326 & 2.75 & 0.420 & 3.47 \\
\hline 20 & 0.319 & 3.64 & 0.409 & 4.16 & 0.489 & 4.25 \\
\hline $\mathrm{r}$ & \multicolumn{2}{|c|}{$0.957^{*}$} & \multicolumn{2}{|c|}{$0.933^{*}$} & \multicolumn{2}{|c|}{$0.943^{*}$} \\
\hline
\end{tabular}

*Significant at 0.05 probability level. 
that the distance measured can be used to predict LAI in Tifton 85 swards. LAI is a key sward structure variable for the proper understanding of the herbage accumulation processes in pastures (Lemaire \& Agnusdei, 2000). Tiller mass and population density are more easily measured than LAI, justifying further studies in order to allow a better understanding of the relationship with sward LAI and intraspecific competition processes that could generate conditions for using them as predictors of sward LAI and herbage dry matter production.

\section{Conclusions}

1. A tiller size/density compensation mechanism also operates in Tifton 85 pastures.

2. There is an indicative that Tifton 85 bermudagrass tillers operate in groups (clusters) in order to ensure competitive ability and optimize LAI.

\section{Acknowledgements}

To Fapesp (Fundação de Amparo à Pesquisa do Estado de São Paulo), for the financial assistance and support; to the students of GEPF (Grupo de Estudos de Plantas Forrageiras), for their help and cooperation throughout the experimental period; to Professor John Hodgson, Massey University, New Zealand, for the most useful comments and suggestions.

\section{References}

BAHMANI, I.; THOM, E. R.; MATTHEW, C. Effects of nitrogen and irrigation on productivity of different ryegrass ecotypes when grazed by dairy cows. In: ANNUAL MEETING OF THE NEW ZEALAND GRASSLAND ASSOCIATION, 59., 1997, Mangere. Proceedings... Palmerston North: New Zealand Grassland Association, 1997. p. 117-123.

BIRCHAM, J. S.; HODGSON, J. The influence of sward conditions on rates of herbage growth and senescence in mixed swards under continuous grazing management. Grass and Forage Science, Oxford, v. 38, p. 323-331, 1983.

CARNEVALLI, R. A.; SILVA, S. C. da. Avaliação de algumas características agronômicas e ecológicas de plantas da espécie Cynodon dactylon cv. Coastcross para fins de validação de técnicas para ensaios de pastejo com plantas forrageiras. Scientia Agricola, Piracicaba, v. 56, p. 489499, 1999.

CASAL, J. J.; DEREGIBUS, V. A.; SÁNCHEZ, R. A. Variations in tiller dynamics and morphology in Lolium multiflorum Lam. vegetative and reproductive plants as affected by differences in red/far-red irradiation. Annals of Botany, London, v. 56, p. 553-559, 1985.

CHAPMAN, D. F.; LEMAIRE, G. Morphogenetic and structural determinants of plant regrowth after defoliation. In: BACKER, M. J. (Ed.). Grassland of our world. Wellington: SIR Publishing, 1993. p. 55-64.

CHAPMAN, D. F.; ROBSON, M. J.; SNAYDON, R. W. Physiological integration in the clonal perennial herb (Trifolium repens L.). Oecologia, Berlin, v. 29, p. 338347, 1992.

DAVIES, A. The regrowth of grass swards. In: JONES, M. B.; LAZENBY, A. (Ed.). The grass crop. London: Chapman and Hall, 1988. 369 p.

FAGUNDES, J. L.; SILVA, S. C. da; PEDREIRA, C. G. S.; SBRISSIA, A. F.; CARNEVALLI, R. A.; CARVALHO, C. A. B.; PINTO, L. F. M. Índice de área foliar, interceptação luminosa e acúmulo de forragem em pastagens de Cynodon spp. sob diferentes intensidades de pastejo. Scientia Agricola, Piracicaba, v. 56, n. 4, p. 11411150, 1999.

FRAME, J. Herbage mass. In: HODGSON, J.; BAKER, R. D.; DAVIES, A.; LAIDLAW, A. S.; LEAVER, J. D. (Ed.). Sward measurement handbook. Maidenhead: British Grassland Society, 1981. p. 39-69.

GRANT, S. A.; BARTHRAM, G. T.; TORVELL, L.; KING, J.; SMITH, H. K. Sward management lamina turnover and tiller population density in continuously stocked Lolium perenne - dominated swards. Grass and Forage Science, Oxford, v. 38, p. 333-344, 1983.

HERNÁNDEZ GARAY, A.; MATTHEW, C.; HODGSON, J. Effect of spring management on perennial ryegrass and ryegrass-white clover pastures -2 : tiller growing points densities and population dynamics. New Zealand Journal of Agricultural Research, Wellington, v. 40 , p. $35-40,1997$. 
HERNÁNDEZ GARAY, A.; MATTHEW, C.; HODGSON, J. Tiller size-density compensation in ryegrass miniature swards subject to differing defoliation heights and a proposed productivity index. Grass and Forage Science, Oxford, v. 54, p. 347-356, 1999.

KORTE, C. J. Tillering in "Grasslands Nui” perennial ryegrass swards -2 : seasonal pattern of tillering and age of flowering tillers with two mowing frequencies. New Zealand Journal of Agricultural Research, Wellington, v. 29 , p. $629-638,1986$.

LANGER, R. H. M. How grasses grow. $2^{\text {nd }}$ ed. London: E. Arnold, 1979. 66 p.

LEMAIRE, G.; AGNUSDEI, M. Leaf tissue turn-over and efficiency of herbage utilisation. In: LEMAIRE, G.; HODGSON, J.; MORAES, A.; CARVALHO, P. C. F.; NABINGER, C. (Ed.). Grassland ecophysiology and grazing ecology. Wallingford: CAB International, 2000. p. $265-288$.

LONSDALE, W. M.; WATKINSON, A. R. Light and selfthinning. New Phytologist, London, v. 90, p. 431-445, 1982.

McMAHON, C. Size and shape in biology. Science, Washington, v. 179, p. 1201-1204, 1973.

McMAHON, C.; KRONAUER, R. E. Tree structures: deducing the principle of mechanical design. Journal of Theoretical Biology, London, v. 59, p. 443-466, 1976.

MATTHEW, C.; ASSUERO, S. G.; BLACK, C. K.; SACKVILLE HAMILTON, N. R. Tiller dynamics of grazed swards. In: LEMAIRE, G.; HODGSON, J.; MORAES, A.; CARVALHO, P. C. F.; NABINGER, C. (Ed.). Grassland ecophysiology and grazing ecology. Wallingford: CAB International, 2000. p. 127-150.
MATTHEW, C.; LEMAIRE, G.; SACKVILLE HAMILTON, N. R.; HERNÁNDEZ GARAY, A. A modified self-thinning equation do describe size/density relationships for defoliated swards. Annals of Botany, Oxford, v. 76, p. 579-587, 1995.

NIKLAS, K. J. Plant allometry: the scaling process. Chicago: University of Chicago Press, 1994. 395 p.

PARSONS, A. J.; LEAFE, E. L.; COLLET, B.; STILES, $\mathrm{W}$. The physiology of grass production under grazing 1: characteristics of leaf and canopy photosynthesis of continuously grazed swards. Journal of Applied Ecology, Oxford, v. 20, n. 1, p. 117-126, 1983.

SACKVILLE HAMILTON, N. R.; MATTHEW, C.; LEMAIRE, G. In defence of the $-3 / 2$ boundary rule: a reevaluation of self-thinning concepts and status. Annals of Botany, Oxford, v. 76, p. 569-577, 1995.

SBRISSIA, A. F.; SILVA, S. C. da; CARVALHO, C. A. B.; CARNEVALLI, R. A.; PINTO, L. F. M.; FAGUNDES, J. L.; PEDREIRA, C. G. S. Tiller size/population density compensation in Coastcross grazed swards. Scientia Agricola, Piracicaba, v. 58, n. 4, p. 655-665, 2001.

UNITED STATES. Soil Survey Staff. Department of Agriculture. Soil Management Support Services. Agency for International Development. Keys to soil taxonomy. $4^{\text {th }}$ ed. Blacksburg, 1990. 423 p. (Technical Monography, 6).

VOLENEC, J. J.; NELSON, C. J. Responses of tall fescue leaf meristem to $\mathrm{N}$ fertilization and harvest frequency. Crop Science, Madison, v. 23, p. 720-724, 1983.

YODA, K.; KIRA, T.; OGAWA, H.; HOZUMI, K. Intraspecific competition among higher plants - XI: selfthinning in overcrowded pure stands under cultivate and natural conditions. Journal of Institute of Polytechnics Series D, Osaka, v. 14, p. 107-129, 1963. 